\title{
REDUCTION OF SOME HEAVY ELEMENTS FROM POLLUTED WATER USING THE BIOLOGICAL ADSORPTION TECHNQUE BY DRY ALGAE
M. R. Z. Al-Qaisi ${ }^{1}$
R. A. Abdul-Jabbar ${ }^{1}$
Assist. Prof. \\ Researcher \\ A. A. Al-Hussieny ${ }^{2}$ \\ Researcher
}

College of Science University of Tikrit In Partial ${ }^{1}$

Abstract:

Ministry of Science and Technology, Baghdad-Iraq ${ }^{2}$

The biological adsorption technique was used with the powder of (Chara virgata, Cladophora fuebllornei) algae with a dry weight of $0.5 \mathrm{~g}$ to treat water contaminated with heavy elements of lead, cadmium, copper, chromium and iron at the two following different locations in Baghdad: AlWaziriyah Batteries factory, and Tanning \& Leather Factory. The experiments were performed at a pH 6 and at a speed of $100 \mathrm{rpm}$ in an electric vibrator. The chara virgata showed high removal ratios $100 \%$ of lead, cadmium, and iron respectively in the first half hour of the experiment, while the chromium and copper removal rates ranged from $74.6-100 \%, 73.2-100 \%$ with $0.5-3$ hour treatment time respectively. The results of Cladophora fuebllornii were different for the chromium element with removal rates ranging from $77.7-100 \%$ and with a treatment time of $\mathbf{0 . 5 - 2}$ hours respectively .Copper removal rates ranged between 83.6-100\% and 0.5-1.5 hours. Lead, cadmium, and iron also had 100\% removal rates, respectively within the first half hour of the experiment. The analysis of the infrared device (FTIR) for the sample of the two-algae used in the experiments proved the presence of the active groups in the cellular walls of each alga, namely carboxyl, hydroxyl, alkyl, amine, and amide groups, which are responsible for bonding heavy element that present in the polluted water.

Keywords: The vital adsorption, heavy elements, algae dry and active groups.

Part of M.Sc. thesis of the $1^{\text {st }}$ auther.

القيسي وآخرون

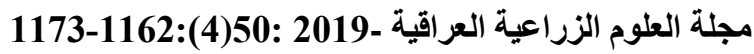

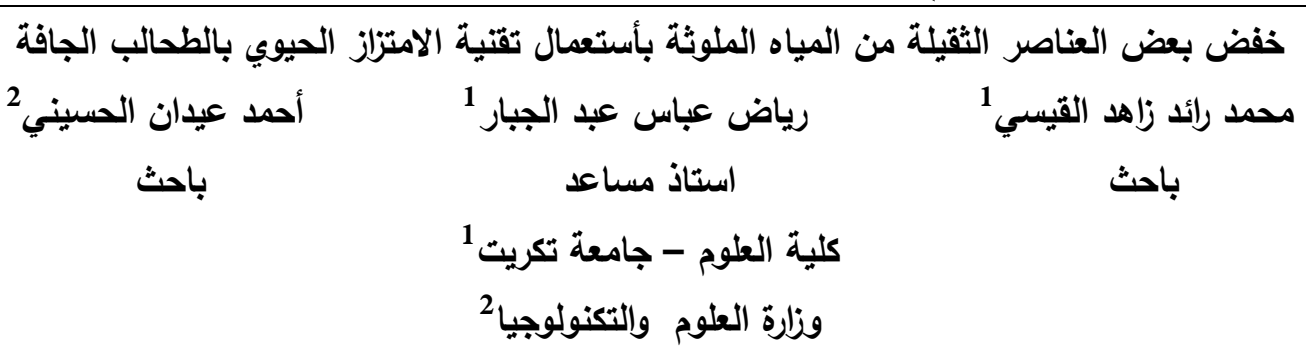

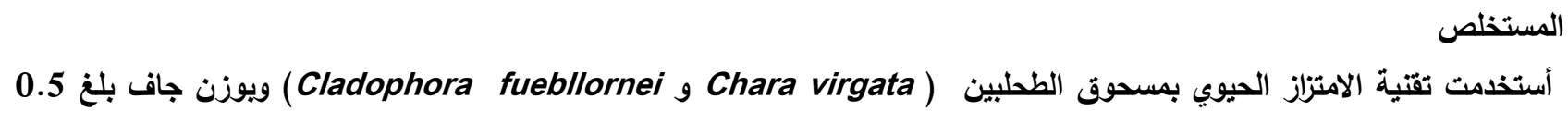
غم لكل منها لمعالجة المياه الملوثة بالعناصر الثقيلة والمتمثلة بعنصر الرصاص والكادميوم والنحاس والكروم والحديد ولموقعين مختلفين

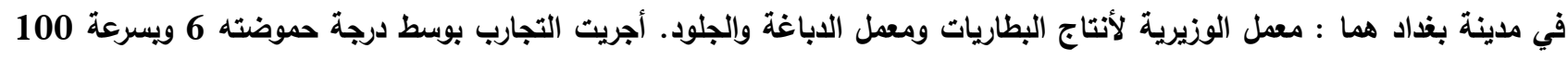

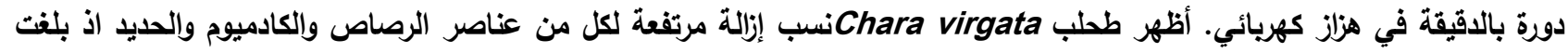

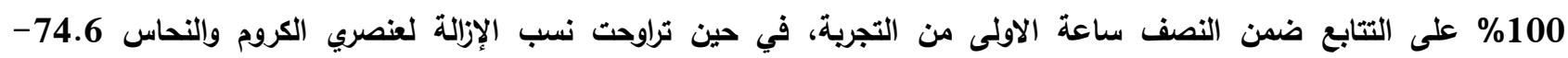

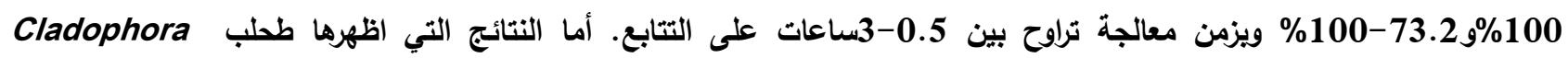
fuebllornei

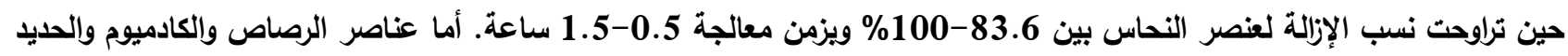

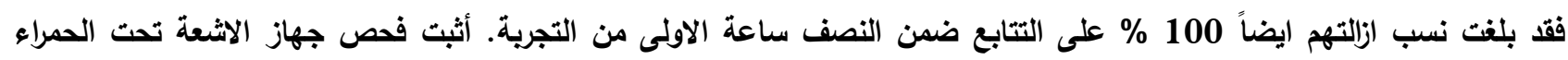

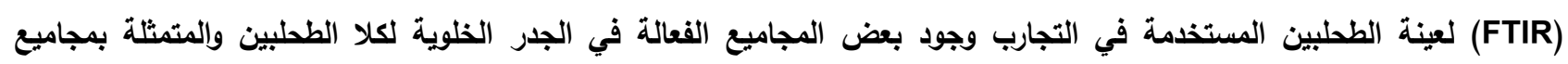

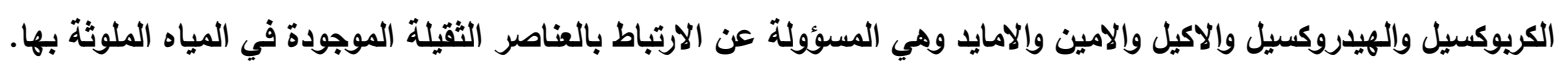
الكلمات المفتاحية: الامتزاز الحيوي والعناصر الثقيلة والطحالب الجافة والمجاميع الفعالة. البحث مستل من رسالة الباحث الاول

*Received:12/8/2018, Accepted:2/12/2018 


\section{INTRODUCTION}

Water is the origin of life on our planet, It is a fundamental factor in all biochemistry interactions in living organisms, The survival of ecosystems depends on the presence of water (8). Its existence is a necessary for plant growth and is a permanent or temporary habitat for various living organisms, Pollution of the aquatic environment is one of the major global obstacles of concern to governments and peoples all over the world Pollution threatens human health, the life of aquatic animals and impedes industrial, agricultural and urban development (21). That the increasing problem of pollution of the environment and the global attention it receives and the pressures on the industry by environmental protection organizations have required the contribution of industry to find solutions to these problems, began modern industrial projects not only plans to build the units' treatment water industrial but to establish special units for wastewater treatment, Making it suitable for re-use. Water pollution causes a change in the physical and chemical properties of water, This causes the amount of usable water to be endangered (14). The amount of fresh water is limited ( $2 \%$ only ) of the total water quantity, which constitutes $71 \%$ of the earth's surface (21). The use of water in industrial processes results in billions of cubic meters of industrial wastewater, which contains large types of heavy elements and organic compounds, which vary depending on the nature of production and the type of material used in each industry and are more toxic than sewage. The industries are used heavy metals where are very dangerous to humans because of the inability of water to dispose of these elements (23). Heavy elements have effects on the physiology of the human body. Cadmium and arsenic can cause cancer, while lead, chromium, and copper cause damage to the brain and damage to bones (28). In the past few years, attempts increased on environmental protection organizations to push scientists to develop new ways of eliminating contaminants. Which has led to increased interest in the use of microorganisms to remove heavy elements with promising economic techniques that are least harmful to the environment. Bioremediation is an alternative and promising method of removing toxic heavy elements from polluting ecosystems (20). The use of biological adsorption technology in this area is one of the most important methods, an abiotic chemicalphysical process that occurs naturally in a particular biomass and is mainly intended to combine of pollutants to the structure External cell wall (3). It has been scientifically proven and based on the studies conducted by researchers that one of the most material that has the characteristic of adsorption is the use of dried algal biomass because of the unique features of the ability to resist the toxins of heavy elements with high concentration On the other hand, it can be used more than once in the treatment and it is not necessary to provide cultivation media to sustain them, either in terms of storage can be stored for long periods at room temperature and do not need to be purified and available in large quantities in the bodies of water. It possesses a large surface area and high efficiency in the process of treatment in addition to it is environmentally friendly (1). Therefore, the study aims to reduce pollutants of industrial waste water with heavy metals using environmentally friendly materials through vital adsorption alga technique.

\section{MATERIALS AND METHODES 1-Study sites}

Two different sites were selected in the current study within Baghdad governorate due to the presence of pollutants (heavy elements) and these sites were as follows: The first site is the General Company for Batteries Industry located in the Waziriya area and the second site is the tanning and leather factory located in the Zafaraniya area. The map below shows the selected study sites. 


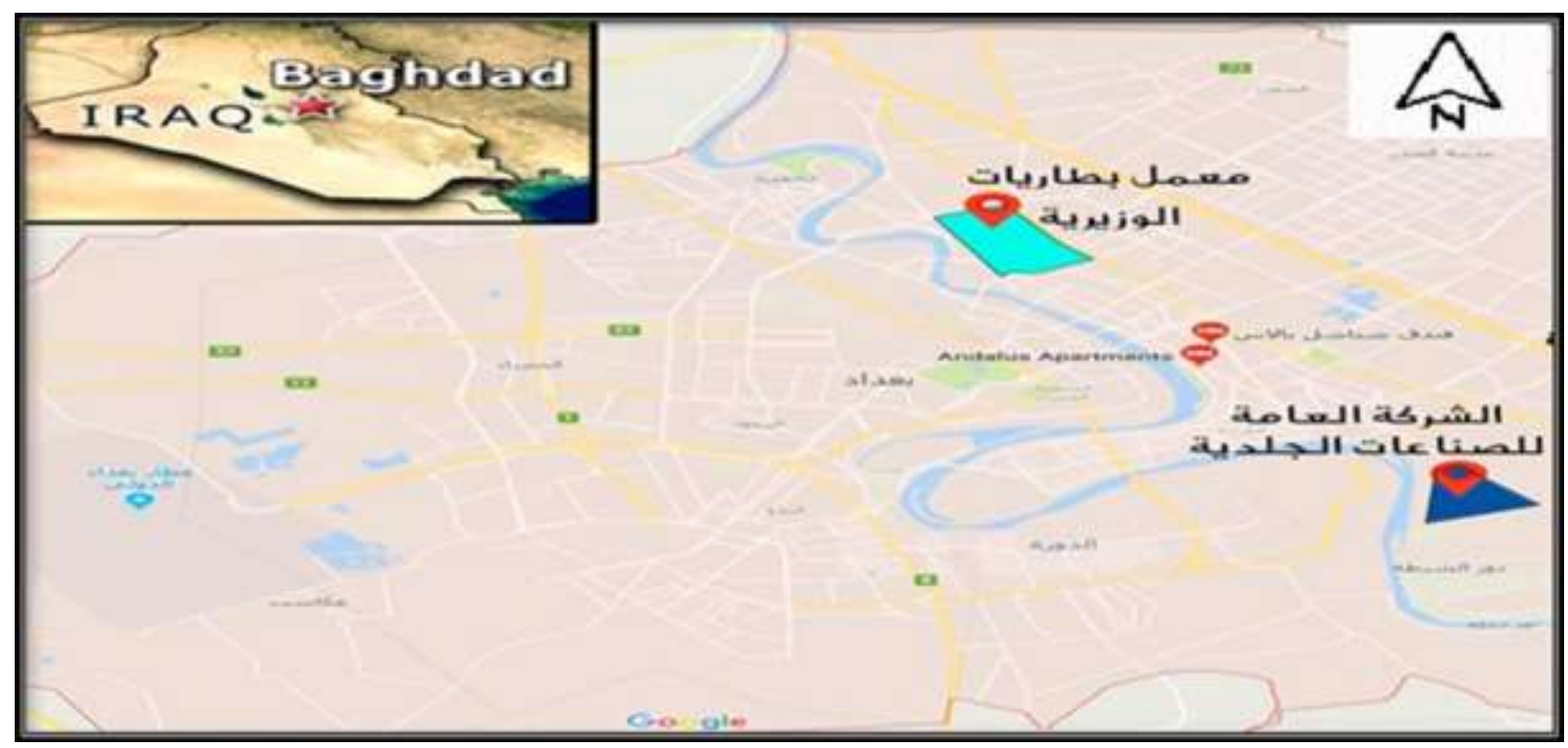

Map 1. the selected study sites within the city of Baghdad

\section{2-Collect samples of Chara virgata algae}

Samples were collected for algae from the Tigris river at the site behind the University of Baghdad / Al-Jadriya. which was classified by (18) .The samples were then washed in tap water and then washed three times with distilled water to remove the residue of sand and salts. Samples of algae were diagnosed through the diagnostic source adopted in the diagnostic process by taking measurements of the dimensions of the algae and its shape Based on (6). The samples were dried at room temperature for two days, grinded by an electric mill and sifted by a $1 \mathrm{~mm}$ diameter sieve to obtain 500-600 microns of Chara virgata algae, algal powder was put in polyethylene bottles and samples stored in the refrigerator at $4{ }^{\circ} \mathrm{C}$ Use them by method (16).

\section{3-Collect samples of Cladophora fuebllornei} algae

The pure isolate of algae was obtained from the Ministry of Science and Technology laboratories by the Environment and Water
Directorate in a pure and highly intensive manner, which was identified by (2). It was brought to the laboratory and some laboratory tests were carried out for isolation to ensure purity. The cultivation experiments were then carried out using the appropriate nutrient media (Chu-No.10) for growing so that we could obtain the appropriate biomass for the biological adsorption process to treat and reduce concentrations of heavy elements.

\section{4- The cultivation media}

Chu-No.10 was used in the preparation of this media, according by (10). the cultivation media prepared as a stock solution and stored in the refrigerator at $4{ }^{\circ} \mathrm{C}$ until use. it was prepared by taking $2.5 \mathrm{ml}$ of each stock solution per liter of deionized distilled water with $\mathrm{pH} \quad 6.8-7$ and it sterilized by Autoclaving at $121^{\circ} \mathrm{C}, 1.5$ atmosphere for 20 minutes. Table (1) Shows the compounds of the cultivation media which was stored in the refrigerator at $4{ }^{\circ} \mathrm{C}$ until use.

Table 1. Shows the components of the cultivation media modification

\begin{tabular}{|c|c|c|}
\hline $\begin{array}{c}\text { Number of stock } \\
\text { solution }\end{array}$ & $\begin{array}{c}\text { Chemical formula of each } \\
\text { salt }\end{array}$ & $\begin{array}{c}\text { Concentration } \\
\mathrm{gL}^{-1}\end{array}$ \\
\hline 1 & $\mathrm{MgSO}_{4} \cdot 7 \mathrm{H}_{2} \mathrm{O}$ & 10 \\
\hline 2 & $\mathrm{~K}_{2} \mathrm{HPO}_{4}$ & 4 \\
\hline \multirow[t]{2}{*}{3} & $\mathrm{NaNO}_{3}$ & 8 \\
\hline & $\mathrm{CaCl}_{2}$ & 16 \\
\hline 4 & $\mathrm{FeCl}_{3}$ & 0.32 \\
\hline 5 & EDTA-Na & 4 \\
\hline 6 & $\mathrm{NaCl}$ & 30 \\
\hline 7 & $\mathrm{Na}_{2} \mathrm{CO}_{3}$ & 8 \\
\hline \multirow[t]{6}{*}{8} & $\mathrm{MnCl}_{2} .4 \mathrm{H}_{2} \mathrm{O}$ & 0.02 \\
\hline & (NH4) $6 \mathrm{Mo}_{7} \mathrm{O}_{24} \cdot 4 \mathrm{H}_{2} \mathrm{O}$ & 0.028 \\
\hline & $\mathrm{ZnSO}_{4} .7 \mathrm{H}_{2} \mathrm{O}$ & 0.224 \\
\hline & $\mathrm{CuSO}_{4} .5 \mathrm{H}_{2} \mathrm{O}$ & 0.08 \\
\hline & $\mathrm{COCl}_{2} \cdot 6 \mathrm{H}_{2} \mathrm{O}$ & 0.004 \\
\hline & $\mathrm{H}_{3} \mathrm{BO}_{3}$ & 0.288 \\
\hline 9 & $\mathrm{Na}_{2} \mathrm{Sio}_{3}$ & 5.7 \\
\hline
\end{tabular}


5- Testability of Chara virgata and Cladophora fuebllornei powder for adsorption of heavy element ions

The experiments were carried out at room temperature in $500 \mathrm{ml}$ glass bottles, $250 \mathrm{~mL}$ of a water sample for each site was added, $0.5 \mathrm{~g}$ of each algal powder was added with $(\mathrm{pH} \mathrm{6)}$. The bottles were placed in an electric vibrator at $100 \mathrm{rpm}$ and at $25^{\circ} \mathrm{C}$ for $24 \mathrm{~h}$, then $25 \mathrm{ml}$ of the solution used with the algae was filtered after passing through the filter papers (Whatman type), the samples were filtered for seven different times in two stages, the first was six times per half hour, After 24 hours of trial time, the samples were filtered in vials sealed and the concentration of heavy elements was measured using an atomic absorption spectrometer at a wavelength (283.3, 228.8, 357.9, 248.3, $324.8 \mathrm{~nm})$ for each element of lead, cadmium, chromium, iron and copper, respectively to test the efficiency of the algae in removing or reducing concentrations of the heavy elements in water, and by observing the concentration ratios and comparing them to the original concentrations to find out the amount of removal, the percentage removal ratios were calculated based on (27) of the following equation:

The percentage removal ratios $=(X-Y / X) \times 100$ $\mathrm{X}$ : the primary concentration Milligram/ Liter

Y: the secondary concentration Milligram/ Liter

The results were analyzed using the Analysis of ANOVA, and the differences between the mean parameters tested depending on Duncan Mable Range and the SPSS

\section{7- Analysis of infrared FTIR (Fourier- transform infrared)}

This technique was used to illustrate the process of binding the heavy element ions to the active groups on the surface of the adsorbents of the Chara and Cladophora algae, which gives the map of the active groups on these cellular surfaces responsible for the adsorption and explains the adsorption mechanism (17)

\section{RESULTS AND DISCUSSION}

1-Use Chara virgata to treat the pollutant water.
A- Treatment of the pollutant water of the first site : Figure (1) shows the removal efficiency of dried Chara virgata with weighing $0.5 \mathrm{~g}$ of the water sample of the batteries production plant containing concentrations of 35.35 and $0.64 \mathrm{mgL}^{-1}$ for both lead and cadmium respectively. The experiments were conducted at the alkaline medium of $\mathrm{pH} 11.9$, It was modified to an acidic medium of $\mathrm{pH} 6$ at $100 \mathrm{rpm}$ in an electric vibrator and a processing period from 0.5 to 24 hours. The results of the present study showed a rise in the percentage of lead removal percentage between $75.9-100 \%$ in the alkaline medium at 0.5-1.5 hours, while cadmium recorded a $100 \%$ removal rate during the first half hours of the experiment. The increase in the removal ratio in the alkaline medium of these elements is due to the deposition of these ions when they interact with the $\mathrm{OH}^{-}$radicals, which is available in the alkaline solutions where the hydroxides of these elements are formed in $\mathrm{pH} 6$ and above. Therefore, the appropriate $\mathrm{pH}$ of the adsorption should be determined. Lead is remaining dissolve in $\mathrm{pH}$ less than 7 , while the cadmium remains dissolved at less than 6.3 (19). The results recorded when changing the $\mathrm{pH}$ value to 6 were different, the removal ratios reached $100 \%$ of lead and cadmium respectively after half an hour from the starting treatment process. The current results agreed with the study (26) when using dried Chara $s p$ of $0.5 \mathrm{~g}$ in acidic medium to adsorbate lead and cadmium with a concentration of 20 and $1 \mathrm{mgL}^{-1}$ for a sample of the water of the battery factory, the results yielded removal percentage $97 \%, 98.7 \%$, respectively. The results of the statistical analysis when using the natural $\mathrm{pH}$ of the battery factory sample showed significant positive differences for the decrease in the concentration of the lead element only. According to the increase in the time periods, the maximum significant decrease of the element after 1.5 hours of experiment time and after changing the $\mathrm{pH}$ value to 6 . The statistical results showed that there were no significant differences between the two components during the treatment period. 


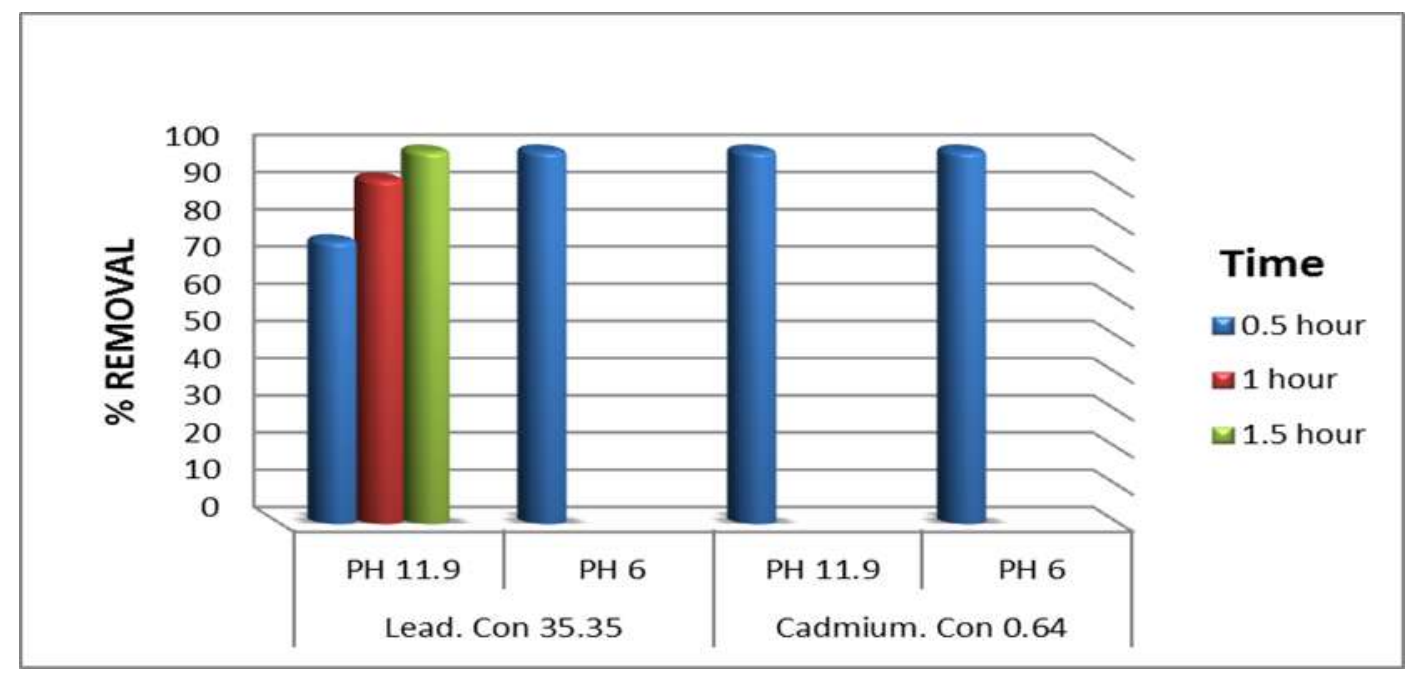

Figure 1. the removal Percentage of heavy elements in wastewater for the batteries factory Using dried Chara vigata algae

B- Treatment of the pollutant water for the second site

Figure(2) shows the removal efficiency of Chara virgata dried powder with weighing $0.5 \mathrm{~g}$ of tanning and leather tanning water sample containing concentrations of 2.60 , $0.75,1.03,23.54,1.16 \mathrm{mgL}^{-1}$ for lead, cadmium, iron, chromium, and copper respectively in $\mathrm{pH} 5.1$ which is represented of natural $\mathrm{pH}$ of the factory sample with modified to $\mathrm{pH} 6$ with an electric vibrator at $100 \mathrm{rpm}$, the period of treatment ranged from 0.5-24 hours. The results of the study showed that in the natural $\mathrm{pH}$ of the factory water, the percentage of removal of the lead, cadmium, and iron was increased by $100 \%$, respectively, within the first half hours of treatment, while the chromium removal ratio ranged from 70.8 to $94.1 \%$, treatment time is $0.5-24$ hours. The depressed chromium removal ratio is due to its elevation concentration. The higher concentration of chromium ions greater than $20 \mathrm{mgL}^{-1}$ in aqueous solutions reduces its diffusion on the surface of the adsorbent, it is Compatible with a study (11). The copper component ranged from $46.5 \%$ to $84.4 \%$ at a time of treatment of $0.5-24$ hours .These results are consistent with the study [9] which showed the effect of metal ions on the adsorption of the copper element as it was found that the element copper may be significantly affected by the presence of other elements because the binding sites available to the element ions become limited. In addition, the decrease in $\mathrm{pH}$ values leads to protons competing with the ions of these elements at one time and impedes the association with the active aggregates, resulting in a decrease in the rate of vital adsorption (18). The results that appeared when changing the $\mathrm{pH}$ value to 6 was different for chromium and copper as the removal ratio of the chromium element ranged 74.6-100\%. Whilst, the copper ranged from $73.2-100 \%$ at the time of treatment $0.5-3$ hours for both elements, while the lead, cadmium, and iron did not different their results, as the removal percentage reached $100 \%$ respectively in the first half hour from the treatment process, when changing in the $\mathrm{pH}$ value. The process of biological adsorption depends strongly on the value of the $\mathrm{pH}$. It determines the strength of the bonding or adhesion between the active sites on the surfaces of the adsorbent and heavy element charge (22). Therefore, the acidic medium diluted is suitable for the adsorption of chromium and copper, which is congruous to the study (13). The results of the statistical analysis showed that there was a positive relationship with the treatment time and the remaining concentration of the heavy elements present in the factory water. There were significant positive differences for both chromium and copper during the treatment time, whether using the natural $\mathrm{pH}$ or the modification to the factory sample. The results showed the remaining of the heavy elements no significant differences. 


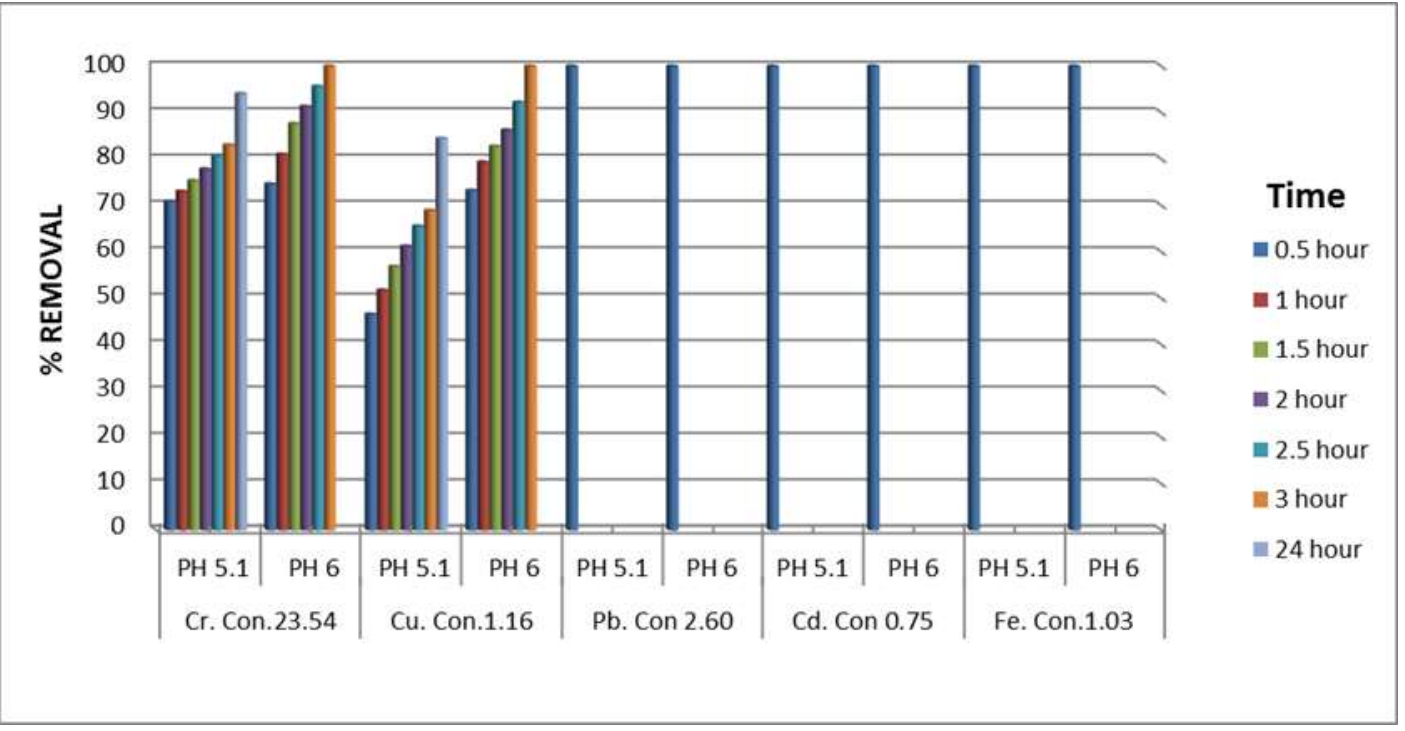

Figure 2. Percentage of heavy elements in wastewater for tanning and leather factory using dried Chara vigata algae

Table $(2,3)$ shows the results of the statistical analysis using SPSS version 20 according to the complete random design (CRD) method to find the significant differences between the mean of the concentrations of the heavy elements of the selected study sites and during different time periods by testing the least significant difference of LSD at the level Probability 0.05 .

Table 2. The concentrations of heavy elements before and after treatment using Chara virgata algae without modification of $\mathbf{P h}$

\begin{tabular}{|c|c|c|c|c|c|c|c|}
\hline \multirow{2}{*}{$\begin{array}{c}\text { Site } \\
\text { Element }\end{array}$} & \multicolumn{5}{|c|}{ The site of tanning and leather } & \multicolumn{2}{|c|}{ The site of batteries } \\
\hline & $\underset{\left(\mathrm{mgL}^{-1}\right)}{\mathrm{Cu}}$ & $\underset{\left(\mathrm{mgL}^{-1}\right)}{\mathrm{Cr}}$ & $\underset{\left(\mathrm{mgL}^{-1}\right)}{\mathbf{F e}}$ & $\underset{\left(\mathrm{mgL}^{-1}\right)}{\mathbf{C d}}$ & $\underset{\left(\mathrm{mgL}^{-1}\right)}{\mathbf{P b}}$ & $\underset{\left(\mathrm{mgL}^{-1}\right)}{\mathrm{Cd}}$ & $\underset{\left(\mathrm{mgL}^{-1}\right)}{\mathbf{P b}}$ \\
\hline $\begin{array}{c}\text { Control } \\
\text { Time }\end{array}$ & 1.16 & 23.54 & 1.03 & 0.75 & 2.60 & 0.64 & 35.35 \\
\hline 0.5 & b0.62 & g6.86 & 0.00 & 0.00 & 0.00 & 0.00 & c8.51 \\
\hline 1 & b0.56 & f6.35 & - & - & - & - & b2.65 \\
\hline 1.5 & b0.50 & e5.80 & - & - & - & - & a0.00 \\
\hline 2 & b0.45 & d5.21 & - & - & - & - & - \\
\hline 2.5 & b0.40 & c4.52 & - & - & - & - & - \\
\hline 3 & b0.36 & b4.00 & - & - & - & - & - \\
\hline 24 & a0.18 & a1.37 & - & - & - & - & - \\
\hline $\begin{array}{l}\text { L.S.D } \\
(\mathbf{0 . 0 5})\end{array}$ & 0.111 & 0.211 & & & & & 0.272 \\
\hline
\end{tabular}

- Values with the same letter are not significantly different from each other

Table 3. The concentrations of heavy elements before and after treatment using Chara virgata algae with modification of $\mathrm{pH}$ to 6

\begin{tabular}{|c|c|c|c|c|c|c|c|}
\hline \multirow{2}{*}{$\begin{array}{c}\text { Site } \\
\text { Element }\end{array}$} & \multicolumn{5}{|c|}{ The site of tanning and leather } & \multicolumn{2}{|c|}{ The site of batteries } \\
\hline & $\underset{\left(\mathrm{mgL}^{-1}\right)}{\mathrm{Cu}}$ & $\begin{array}{c}\mathbf{C r} \\
\left(\mathbf{m g L}^{-1}\right)\end{array}$ & $\begin{array}{c}\mathrm{Fe} \\
\left(\mathrm{mgL}^{-1}\right)\end{array}$ & $\begin{array}{c}\mathbf{C d} \\
\left(\mathrm{mgL}^{-1}\right)\end{array}$ & $\begin{array}{c}\mathbf{P b} \\
\left(\mathrm{mgL}^{-1}\right)\end{array}$ & $\begin{array}{c}\mathbf{C d} \\
\left(\mathrm{mgL}^{-1}\right)\end{array}$ & $\begin{array}{c}\mathbf{P b} \\
\left(\mathrm{mgL}^{-1}\right)\end{array}$ \\
\hline Control & 1.16 & 23.54 & 1.03 & 0.75 & 2.60 & 0.64 & 35.35 \\
\hline 0.5 & b 0.31 & f 5.96 & 0.00 & 0.00 & 0.00 & 0.00 & 0.00 \\
\hline 1 & b 0.24 & e 4.45 & - & - & - & - & - \\
\hline 1.5 & b 0.20 & d 2.90 & - & - & - & - & - \\
\hline 2 & b 0.16 & c 2.03 & - & - & - & - & - \\
\hline 2.5 & b 0.09 & b 1.03 & - & - & - & - & - \\
\hline 3 & a 0.00 & a 0.00 & - & - & - & - & - \\
\hline $\begin{array}{l}\text { L.S.D } \\
(0.05)\end{array}$ & 0.094 & 0.183 & - & - & - & - & - \\
\hline
\end{tabular}

- Values with the same letter are not significantly different from each other. 


\section{2-Use Cladophora fuebllornei to treat the} pollutant water

A-Treatment of the pollutant water of the first site: Figure (3) shows the removal efficiency of the dried Cladophora fuebllorne $i$ algae with weighing $0.5 \mathrm{~g}$ of the water sample of the battery factory containing concentrations 35.35 and $0.64 \mathrm{mgL}^{-1}$ respectively for lead and cadmium. The experiments were carried out at the $\mathrm{pH}$ of the factory sample at 11.9 , It was modified to an acidic medium of 6 in an electric vibrator at $100 \mathrm{rpm}$ and at a time of treatment from 0.5 24 hours. The results of the present study showed a rapid decrease in the concentration of lead and cadmium during the first half hour of the experiment with $100 \%$ elimination rate respectively in the case of natural $\mathrm{pH}$ and the modification of the sample of the water of the factory. The ability of algae varies in the adsorption of heavy elements due to differences in the structure of the cell wall and the positive and negative ion exchange sites on the surface of the external wall shows a high affinity of a particular element, while this property does not appear with other elements $(15,4)$. In the results of the study, the ability of the Cladophora sp algae to absorb the lead element at the natural $\mathrm{pH}$ of the factory water compared to Chara sp in the same location. According to the classification of elements in terms of complexity, the element of lead and cadmium is a light element as it tends to form complex compounds that are fixed in liquids, this is done through covalent and ionic bonds [24]. Which explains the rapid absorption of adsorbent elements within a short period of time. A study (25) also showed that high concentrations of heavy elements lead to high removal rates, due to the presence of a major number of binding sites of elements on the surfaces of algal cells. The results of the statistical analysis showed no significant differences in the normal $\mathrm{pH}$ or the modified of the heavy elements present in the sample of the factory water.

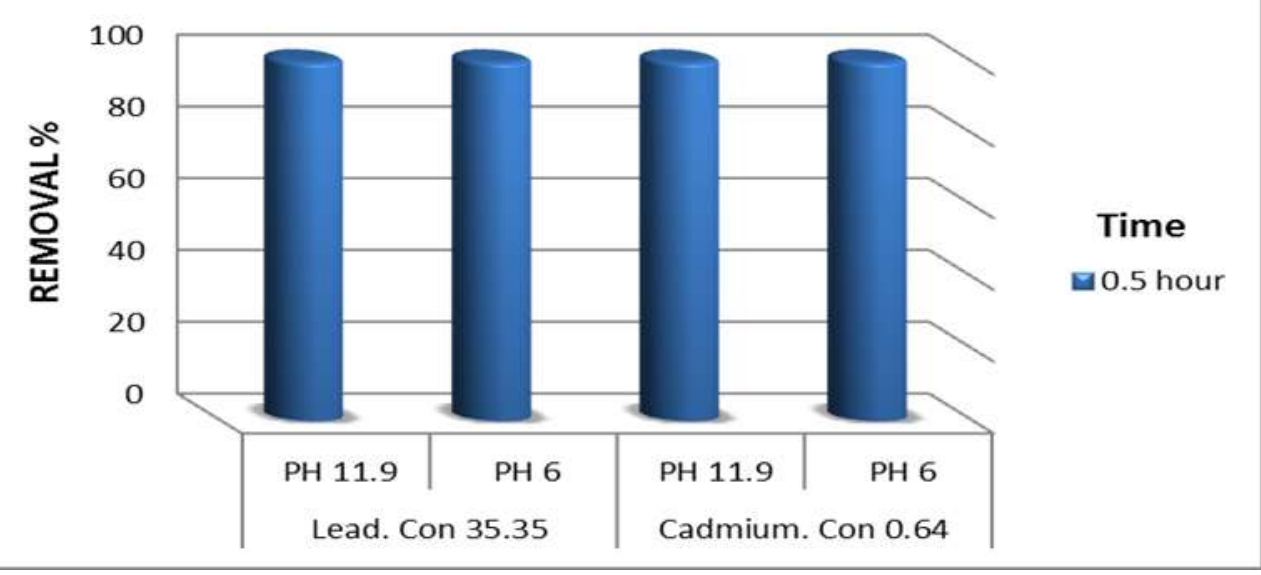

Figure 3. the removal Percentage of heavy elements in wastewater for the battery factory Using dried Cladophora fuebllornei algae

\section{B-Treatment of the pollutant water for the} second site

Figure (4)shows the removal efficiency of the dried Cladophora fuebllornei algae with weighing $0.5 \mathrm{~g}$ of tanning and leather water sample containing concentrations of 2.60, $0.75,1.03,23.54,1.16 \mathrm{mgL}^{-1}$ for lead, cadmium, iron, chromium, and copper respectively. in $\mathrm{pH} 5.1$ which is represented by natural $\mathrm{pH}$ of the factory sample with modified to 6 in an electric vibrator at $100 \mathrm{rpm}$, the period of treatment ranged from 0.5-24 hours. The results of the study at the natural $\mathrm{pH}$ of the factory sample showed a rapid decrease in the concentration of lead, cadmium and iron, with $100 \%$ elimination rate in the first half hour of the experiment. The chromium element was removed between $70.9-100 \%$ at $0.5-2.5$ hours, while the copper recorded removal ratios ranging from $62-100 \%$ at the processing time of $0.5-3$ hours from the starting of the experiment. The results of the change in the value of $\mathrm{pH}$ to 6 the factory water sample were different for chromium and copper as the removal rate of chromium element ranged between $77.7-100 \%$ at the processing time of 0.5-2 hours, while the copper has ranged between 83.6 - $100 \%$ within a processing time 
of $0.5-1.5$ hours from the starting of the experiment. While the lead, cadmium and iron results did not show any differences when the $\mathrm{pH}$ value was changed, with $100 \%$ elimination in the first half hour of the experiment. The adsorption of heavy elements to most biomass types decreases markedly when the $\mathrm{pH}$ decreases and the optimal $\mathrm{pH}$ value is very important to obtain the elevated adsorption. This capacity will decrease with another increase in $\mathrm{pH}$ value (5). As this results shown the rapid susceptibility of the algal mass on adsorption of heavy elements in the acidic $\mathrm{pH}$ 6 only There is a simple gradient in chromium and copper element in the treated due to the presence of effective groups of different in the wavelengths and charge (29). The results of the statistical analysis showed that there were no significant differences in the lead, cadmium, and iron. There were significant positive differences for chromium and copper according to the increase in the time periods of starting the process, whether at the natural $\mathrm{pH}$ or the modified for factory water sample

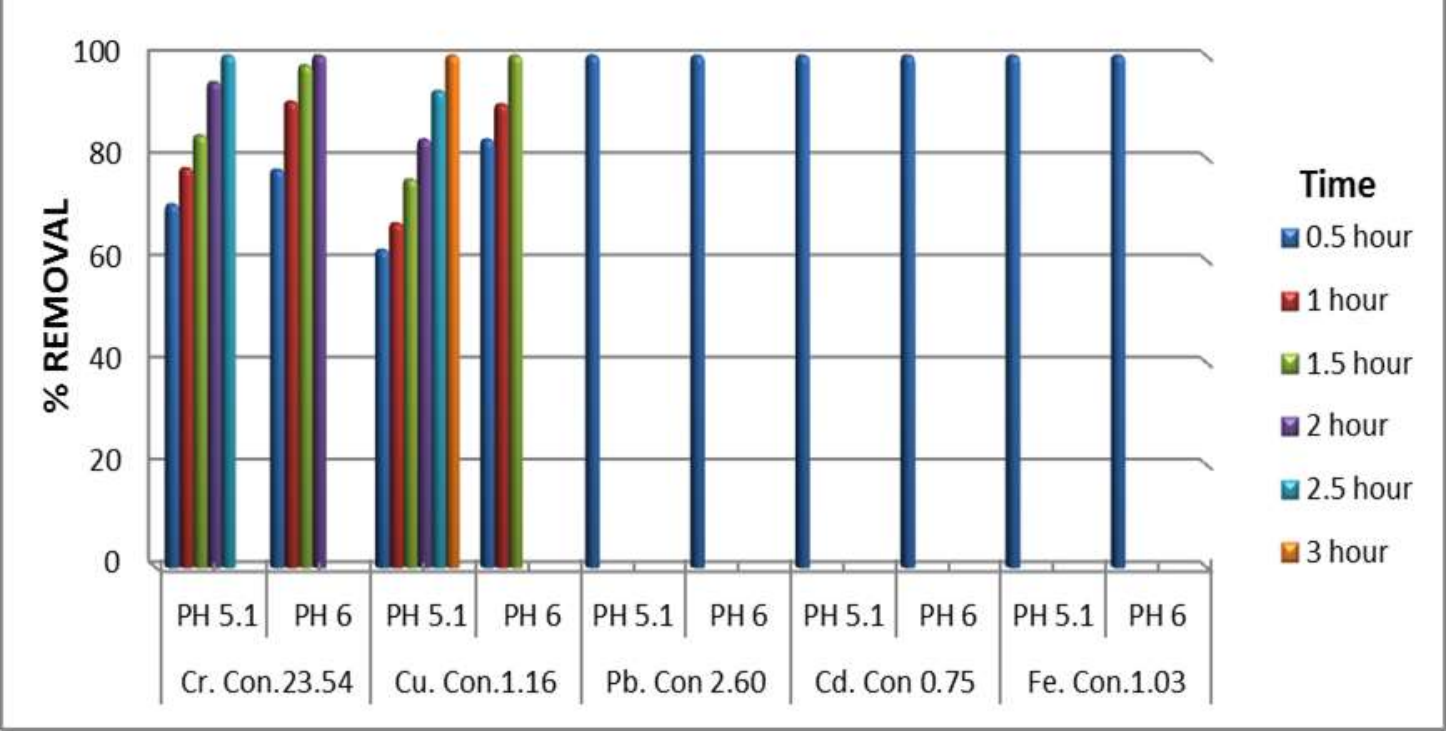

Figure 4 Percentage of heavy elements in wastewater for tanning and leather factory using dried Cladophora fuebllornei algae

Table $(4,5)$ shows the results of the statistical to find the differences between the mean of the analysis of the study sites during different time concentrations of heavy elements at the level periods and at the natural $\mathrm{pH}$ and the modified of probability 0.05 .

Table 4. The concentrations of heavy elements before and after treatment using Cladophora fuebllornei algae without modification of $\mathrm{Ph}$

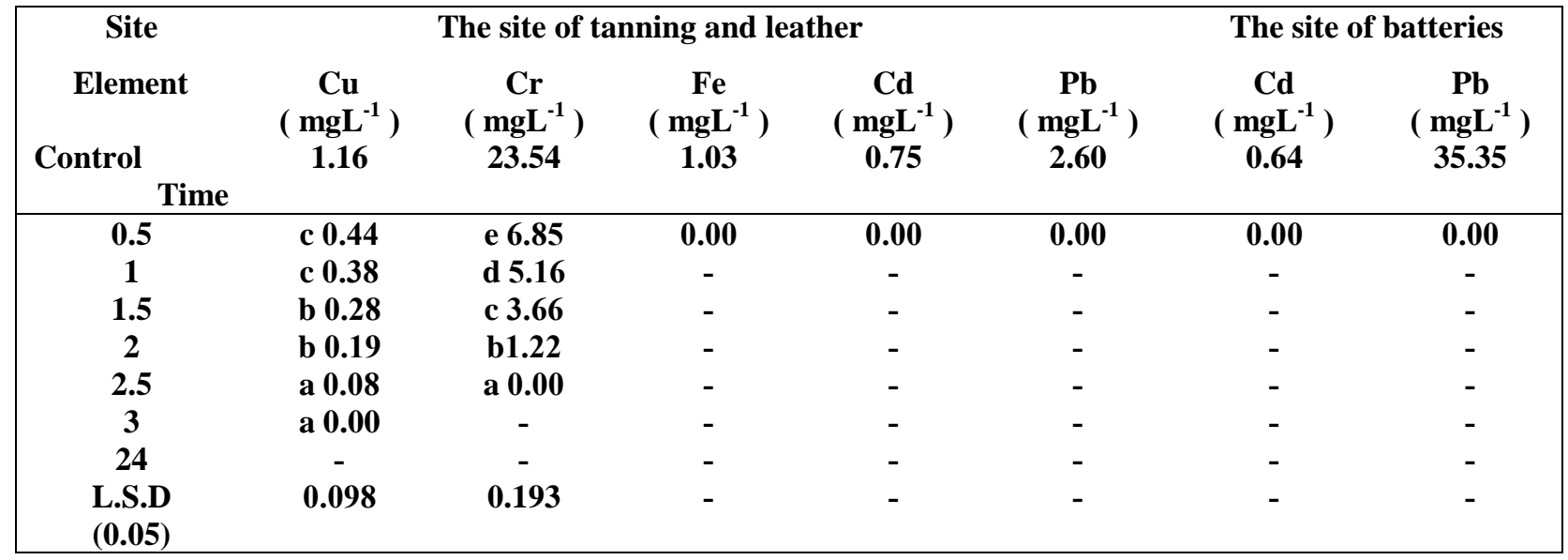


Table 5. The concentrations of heavy elements before and after treatment using Cladophora fuebllornei algae with modification of $\mathrm{pH}$ to 6

\begin{tabular}{|c|c|c|c|c|c|c|c|}
\hline \multirow{2}{*}{$\begin{array}{c}\text { Site } \\
\text { Element }\end{array}$} & \multicolumn{5}{|c|}{ The site of tanning and leather } & \multicolumn{2}{|c|}{ The site of batteries } \\
\hline & $\underset{\left(\mathrm{mgL}^{-1}\right)}{\mathrm{Cu}}$ & $\begin{array}{c}\mathrm{Cr} \\
\left(\mathrm{mgL}^{-1}\right)\end{array}$ & $\begin{array}{c}\mathbf{F e} \\
\left(\mathrm{mgL}^{-1}\right)\end{array}$ & $\begin{array}{c}\mathbf{C d} \\
\left(\mathrm{mgL}^{-1}\right)\end{array}$ & $\underset{\left(\mathrm{mgL}^{-1}\right)}{\mathbf{P b}}$ & $\begin{array}{c}\mathbf{C d} \\
\left(\mathrm{mgL}^{-1}\right)\end{array}$ & $\underset{\left(\mathrm{mgL}^{-1}\right)}{\mathbf{P b}}$ \\
\hline $\begin{array}{c}\text { Control } \\
\text { Time }\end{array}$ & 1.16 & 23.54 & 1.03 & 0.75 & 2.60 & 0.64 & 35.35 \\
\hline 0.5 & с 0.19 & d 5.24 & 0.00 & 0.00 & 0.00 & 0.00 & 0.00 \\
\hline 1 & b 0.11 & c 2.11 & - & - & - & - & - \\
\hline 1.5 & a 0.00 & b 0.43 & - & - & - & - & - \\
\hline 2 & - & a 0.00 & - & - & - & - & - \\
\hline 2.5 & - & - & - & - & - & - & - \\
\hline 3 & - & - & - & - & - & - & - \\
\hline $\begin{array}{l}\text { L.S.D } \\
(0.05)\end{array}$ & 0.059 & 0.089 & - & - & - & - & - \\
\hline
\end{tabular}

3 - Testing of active groups for Chara groups responsible for the biological virgata and Cladophora fuebllornei

The cellular wall of green algae contains a variety of polysaccharides that are different in providing effective groups for the storage and separation of the heavy elements that present in the aquatic solutions. Heavy elements release positive electrical charges while the active groups release negative electrical charges, which lead to adsorption heavy elements and cleaning the water from them (7). FTIR technology was used to investigate and detect the active groups present on the external surfaces of the Chara vigata and Cladophora fuebllornei wall. The active adsorption of lead, cadmium, nickel, chromium, copper and iron elements of carboxyl, hydroxyl, alkyl, amine, amide, and sulfate were identified as active groups $(26,12)$ These groups are responsible for the vital adsorption of the heavy elements . The figure $(5,6)$ shown the active groups of Chara virgata . the Figure $(7,8)$ shown the effective groups of Cladophora fuebllornei with their wavelengths after the treatment process for the selected study sites. active groups have different wavelengths and the charge by the relationship between transmission factor $(\mathrm{T} \%)$ and wavelengths.

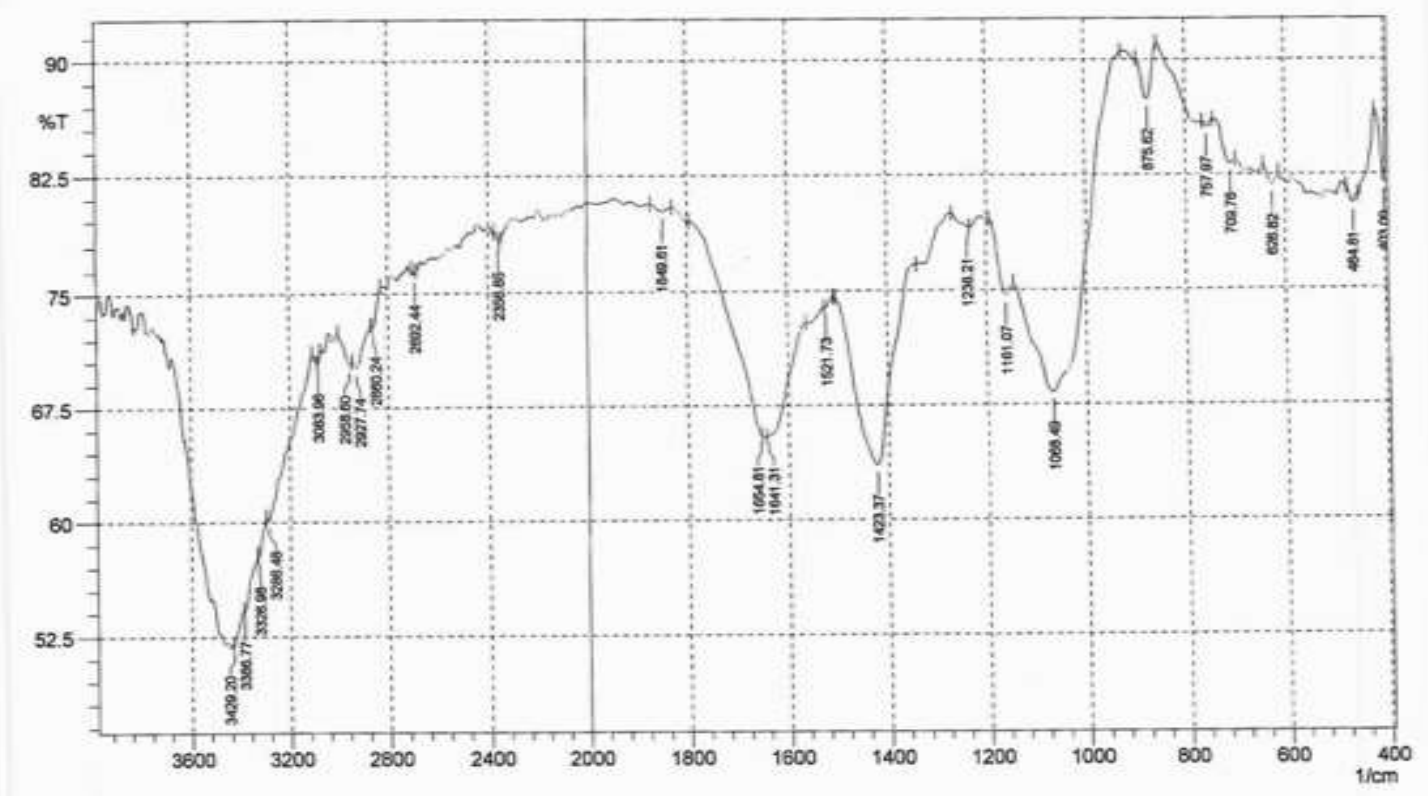

Figure 5. shows FTIR for Chara virgata algae in the Reducing the concentration of heavy elements of the batteries factory 


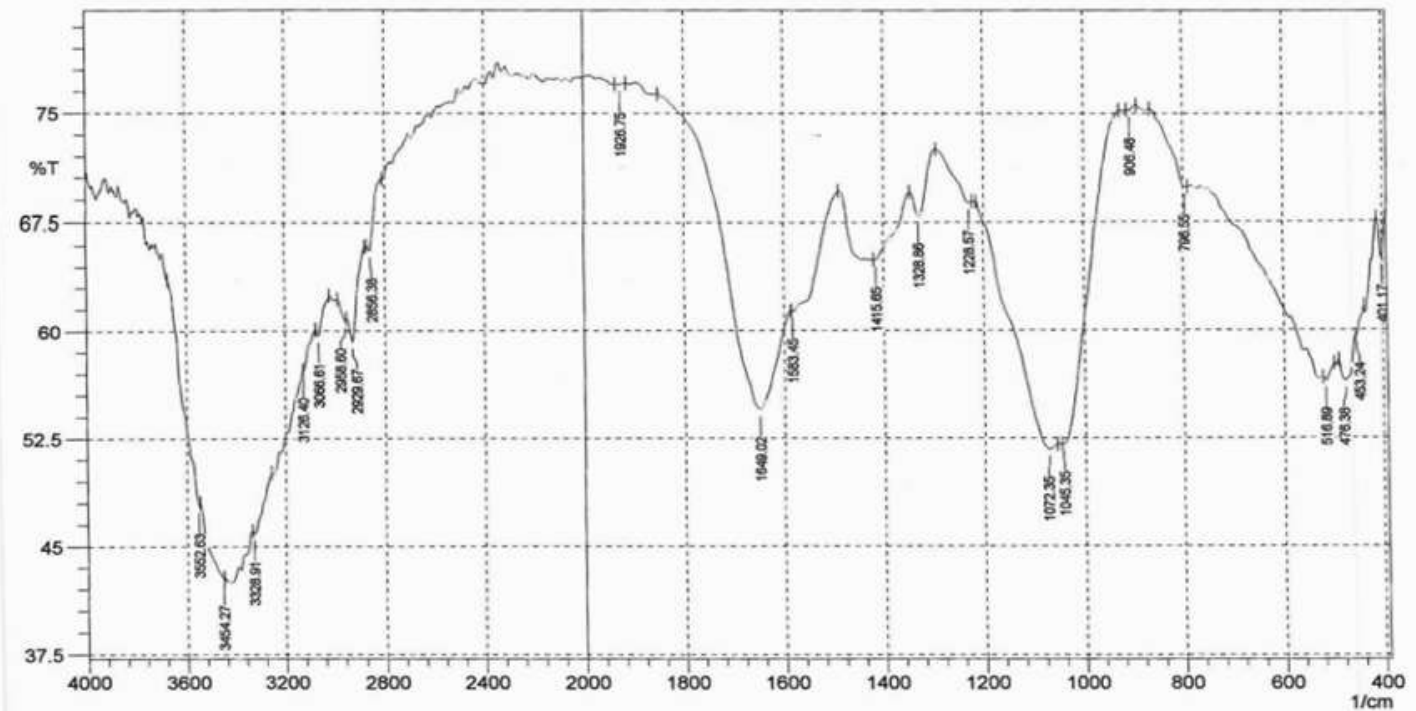

Figure 6. shows FTIR for Chara virgata algae in the Reducing the concentration of heavy elements of the of tanning and leathers factory

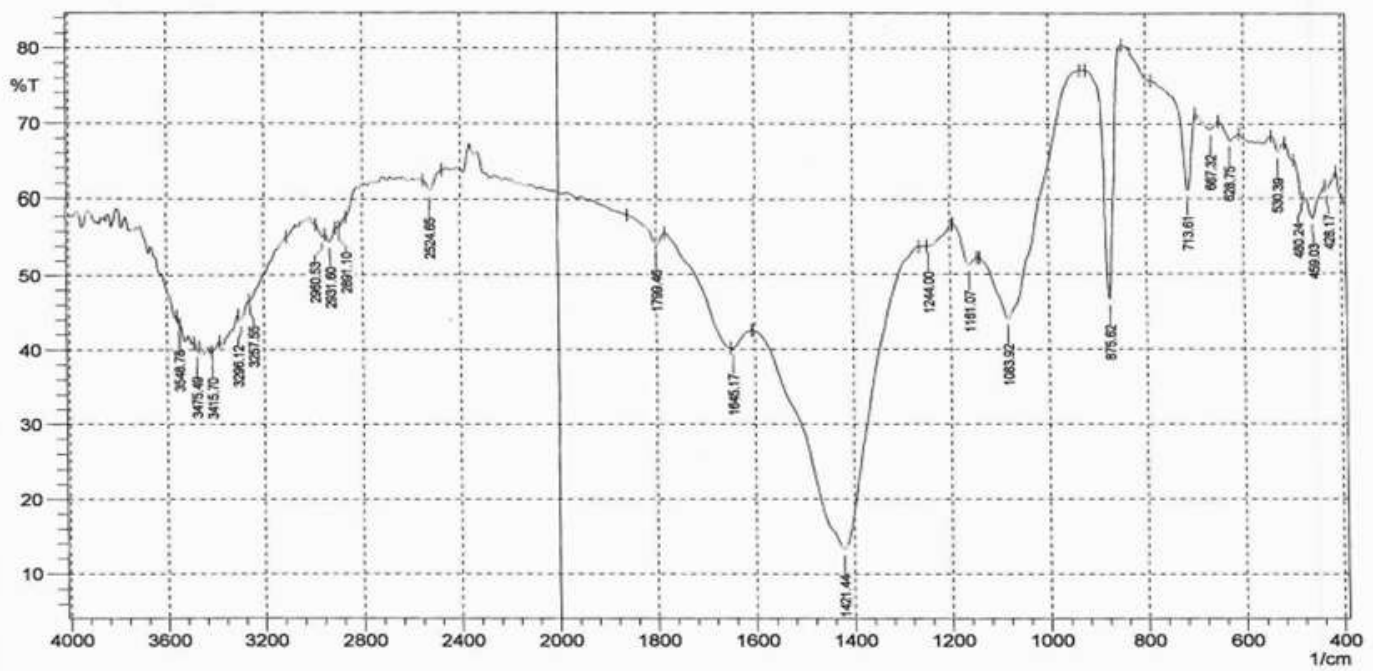

Figure 7. shows FTIR for Cladophora fuebllornei algae in the Reducing the concentration of heavy elements of the batteries factory

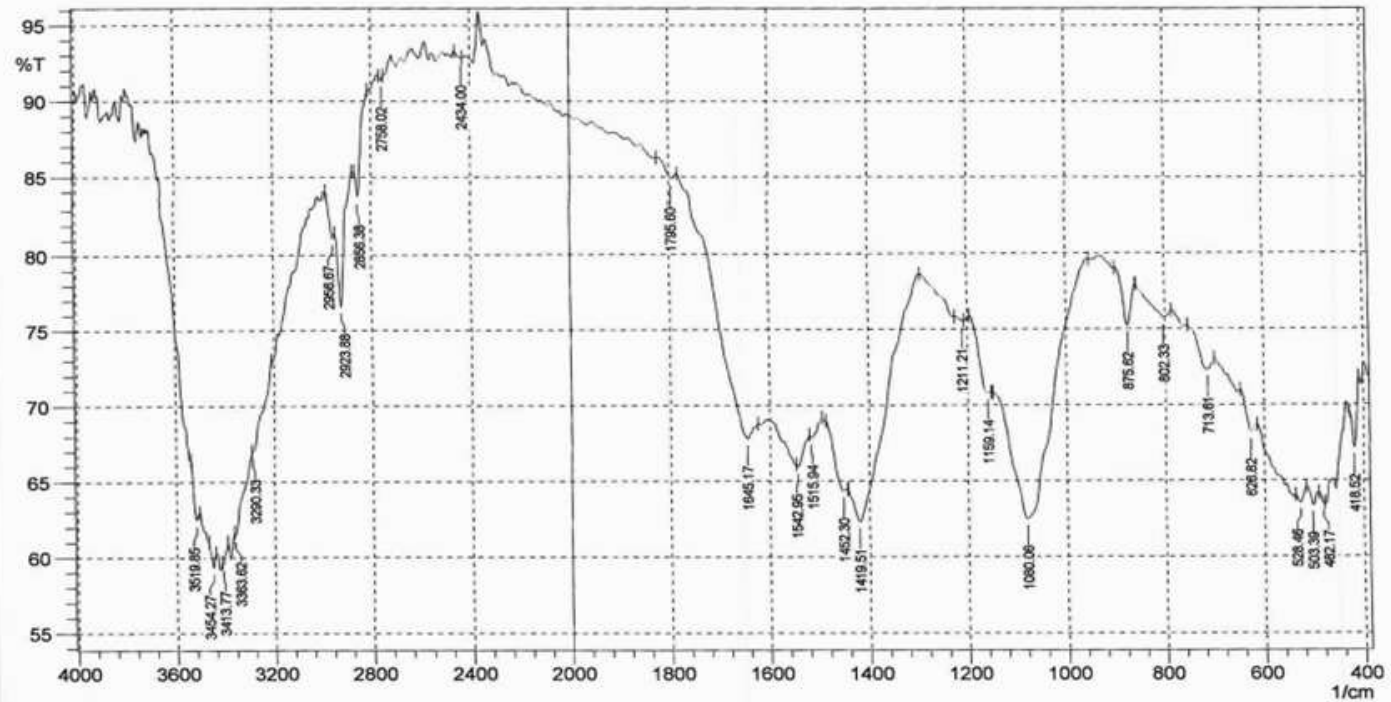

Figure 8. shows FTIR for Cladophora fuebllornei algae in the Reducing the concentration of heavy elements of the of tanning and leathers factory 


\section{REFERENCES}

1-Ahalya, N. , T.V Ramachandara and R.D Kanamadi.2003. Biosorption of heavy metals. Res.J. Chem. Environ .7:71-79

2-Al-Hussieny, A. A.2018. Atlas of The Algae in The Iraqi Aquatic Environment. Scholars press. Book .pp195

3-Chang, N.B.2011. Making a Progress to Speed up the Nitrification and Denitrification Processes in Novel Biosorption Activated Media: Can Archaea be in Concert with Anammox? J Bioprocess Biotechniq 1: 103108

4-Delanoue, J ., P . Lessard and G . Dumas . 1998. Biotreatment from effluents using the cyanobacterium Phormidium bohner, Aquacul . Eng . $17: 57-68$

5-Doshi, H., A. Ray and I.L Kothari .2007. Bioremediation potential of live and dead Spirulina: spectroscopic, kinetics and SEM studies. Biotechnology and Bioengineering 96(6): 1051-1063

6-Edward, G.B., and C.S David.2010. Freshwater Algae Identification and Use as Bioindicators. Printed in Great Britain by Antony Rowe, Ltd. Chippenham, Wilts.pp 285 7-Fourest, E. and B. Volesky. 1996. Contribution of Sulfonate groups and Alginate to heavy metals biosorption by the dry biomass of Sargassum fluitans.Environ. Sci. Technol.,30:277-282

8- Gosling, S.N and N.W Arnell.2013.A global assessment of the impact of climate change on water scarcity. Clim. Chang,pp 115

9-Kaewsarn, P .2000. Single and MultiComponent Biosorption of Heavy Metal Ions by Biosorption from Marine Alga Durvillaea potatorum, Ph.D. Diss.,Environmental Engineering, Griffith University, Queensland 10-Kassim, T.I, H .A AL.Saadi and N . A Salman .1999. Production of some Phyto-and zoo plankton and their use live food for fish larvac Inpress,pp: 1-21

11-Kiran, B., A. Kaushik and C.P Kaushik.2007. Biosorption of $\mathrm{Cr}$ (VI) by native isolate of lyngbya putealis (hh-15) in the presence of salts, J. Hazard. Mater. 141: 662667

12-Kumar, K.S., H.-U Dahms, E.-J Won, J.-S Lee and K.-H Shin .2015. MicroalgaeApromising tool for heavy metal remediation.
Ecotoxicology and environmental safety 113: 329-352

13-Liping D.,Z. Yang,Q. Jie, W. Xinting and Z. Xiaobin.2009. Biosorption of $\mathrm{Cr}(\mathrm{VI})$ from aqueous solutions by nonliving green algae Cladophora albida. Elsevier Ltd. All rights reserved.J. Minerals Engineering,22(4):372377

14- Malik,N., A . Biswas, T . Qureeshi, K . Borana and R . Virha .2010. Bioaccumulation of heavy metals in fish tissues of fresh water lake of Bhopal . Environ . Monit . Asses . $160: 267-276$

15-Mehta, S.K and J.P Gaur .2005. Use of algae for removing heavy metal ions from wastewater: progress and prospects. Critical Reviews in Biotechnology, 25(3): 113-152 16-Mello,N.T.2005.Use of macro algae in the removal of $\mathrm{Ni}$ in aqueous solution

17-Naja,G.M., C.Mustin, B.Voleskey and J. Bertheline.2005.Ahighrosoulution titrator: anew approach to studying binding sites of microbial biosorbents. Water Research,39:579-588

18- Prescott, G.W.1964.The alga: A review. Houghton Mifflin comp. Boston, pp:436

19-Quintelas,C and T. Tavares.2008. Biosorption of $\mathrm{Cr}$ by three different bacterial supported on granular activated carbon A comparative study .J. Hazardous Materials, 153:799-809

20-Rodriguez-Zavala, J.S., J.D Garcia-Garcia, M.A Ortiz-Cruz and R. Moreno-Sanchez. 2007.Molecular mechanisms of resistance to heavy metals in the protist Euglena gracilis. Journal of Environmental Science and Health Part A 42(10): 1365-1378

21-Saadi, H. A. 2006. Basics of ecology. Dar Al Yazouri for Publishing and Distribution Amman, Jordan. pp: 23,253,347

22-Sameera, V., C.H Naga Deepthi, G. Srinu Babu and Y. Ravi Teja.2011. Role of Biosorption in Environmental Cleanup, Microbial \& Biochemical Technology.pp:2-8 23-Samurai, H.and J. Mohammed.2002. Study of the Concentration of Heavy Elements in Industrial Waste Water to the General Company for the Manufacture of Medical Drugs in Samarra and find the Necessary Treatment. M.Sc. Thesis, Faculty of Engineering, University of Tikrit 
24-Schiewer,S. and B. Volesky.2000. 27-Uten, F.1978.Standard methods and Biosorption processes for heavy metals terminology in fin-fish nutrition from Proc. removal.In Environ. Micro-Metal Interaction World Symp. on finfish nutrition and fish feed :Lovely, D. R., Ed.; ASM ress: Washington, D.C.;pp:329-357 technology, Hamburg. 2:20- 23

25-Sivarajasekar,N., R. Baskar and V. Balakrishnan.2009.Biosorption of an Azo Dye From aqueous solutions on to spirogyra sp.Jornal of the University of Chemical Technology and Metallurgy,44(2):157-164 26-Thijar ,L.A., A.A Al-Hussieny, S. N Hani and M.T Rosal .2014. Biosorption of lead, cadmium and nickle from industrial wast water by using dried macroalgae, Baghdad Journal of Science.2(11): 9 28-Wang, J. and C. Chen.2009. Biosorbents for heavy metals removal and their future, Biotechnol. Advances, 27, 195-226

29-Yuan, Zhao.2012. Heavy Metals in Wastewater: Their Removal Through Algae Adsorption and Their Roles in Microwave Assisted Pyrolysis of Algae, A Thesis Submitted to the Faculty of the Graduate School of the University of Minnesota.. 